Egyptian

Orthodontic Journal

\title{
EFFECT OF TOPICAL FLUORIDE ON THE MECHANICAL PROPERTIES OF FORCE-DISPENSING COMPONENTS IN ORTHODONTICS
}

\author{
Sara M.H. El-kabbany ${ }^{1}$, Samir A. Ibrahim², Ahmed E.A. Salama ${ }^{3}$, \\ Heba Shalaby ${ }^{4}$, Fatma Abdel-Aziz ${ }^{5}$
}

\section{ABSTRACT:}

Compromised oral hygiene, a frequent complication with orthodontic treatment, can lead to enamel demineralization and decay. Therefore, orthodontists commonly prescribe a daily topical fluoride. The purpose of this investigation was to study the effect of two types of fluoride prophylactic gels on: 1. The mechanical properties of nickel titanium ( $\mathcal{N} i-T_{i}$ ) and stainless steel (SS) orthodontic wires. 2. Stress relaxation characteristics of conventional, memory elastomeric chains and $\mathcal{N} i T i$ closed coil springs. To fulfill this purpose, the studied sample was divided into three equal groups of ten according to the type of test media; acidulated fluoride agent, neutral fluoride agent and artificial saliva (control). The wires were tested in their received condition and after one hour and half immersion in the test media at $37^{\circ} \mathrm{C}$. The loading and unloading elastic modulus and yield strength of the

1- Assistant Lecturer of Orthodontics, Faculty of Dental Medicine (For Girls), Al-Azhar University.

2- Professor of Orthodontics and Vice Dean of Faculty of Dental Medicine (For Girls), Al-Azhar University.

3- Assistant Professor and Head of Orthodontic Department, Faculty of Dental Medicine (For Girls), Al-Azhar University.

4- Professor and Head of Dental Materials Department, Faculty of Dental Medicine, Misr International University.

5- Lecturer of Orthodontics, Faculty of Dental Medicine (For Girls), Al-Azhar University.

* The current study was extracted from MDSc. thesis in Orthodontics, Orthodontic Department, Faculty of Dental Medicine (For Girls), Al-Azhar University. 
Egyptian

Orthodontic Journal

wires were measured with a 3-point bend test on a universal testing machine. The elastomeric chains and the closed coil springs were subjected to stress relaxation test. Force readings were taken at initial activation and then at time intervals 1hour, 24 hours, 1, 2, 3 and 4 weeks. The results concluded that 1. Topical fluoride agents decrease the functional unloading mechanical properties of $\mathcal{N} i-\mathcal{T}_{i}$ and SS orthodontic wires which could contribute to prolonged orthodontic treatment.

2. $\mathcal{N} i-T_{i}$ coil springs and memory elastomeric chains were not significantly affected. So, they are recommended in association with Topical fluoride agents for delivering steady-continuous force for a period up to four weeks.

\section{INTRODUCTION}

Fixed orthodontic appliance must include force delivering components such as arch wires, coil springs, elastics, elastomeric chains, threads and modules. Synthetic elastomeric chain was introduced in 1960s. It is inexpensive, hygienic, easy manipulated and requires little or no patient cooperation. However, it absorbs saliva, stains and deforms permanently after it is stretched in the oral cavity. Also, it loses its force rapidly because of stress relaxation and can result in a less desirable force value to conduct tooth movement. ${ }^{1-4} \mathrm{Ni}-\mathrm{Ti}$ coil springs were introduced in 1970s and provided an alternative to the use of the elastic products. ${ }^{5-8}$

The amount of force decay per time was dependent on multiple effective variables such as type of the elastomers, time, tooth movement, temperature changes, $\mathrm{pH}$ variations, oral fluoride rinses, disinfectant solutions, salivary enzymes and masticatory forces.

Despite the advances in orthodontic materials and techniques in recent years, the development of decay around the brackets continues to be a problem. Preventive programs with fluoride can reduce the risk of demineralization during orthodontic treatment, especially if they are associated 
with oral hygiene instructions and patient motivation. There are several methods for delivering fluoride to teeth including topical fluorides and fluoride-releasing materials. The mechanism of fluoride action has been shown to increase the resistance of enamel to acids and the maturation rate of enamel, and it also interferes with the metabolism of microorganisms. ${ }^{9}$

The effect of fluoride on orthodontic wires will be reviewed from the view point of corrosion resistance, mechanical properties and Frictional resistance. a) Corrosion resistance: The effect of fluoride on titanium and its alloys have been investigated from the viewpoint of corrosion or discoloration by several workers. ${ }^{10-24}$ It was clarified that the corrosion resistance of titanium and its alloys markedly decreases in fluoride solutions because the fluoride ions combine with hydrogen ions in the acidic environment to form hydrofluoric acid which dissolves the protective oxide layer on the surface of titanium and its alloys.

b) Degradation of mechanical properties (degradation in performance): Fracture or degradation of the mechanical properties caused by hydrogen is generally termed hydrogen embrittlement. This hydrogen embrittlement is often represented as a reduction in both fracture strain and area, and is accompanied by a change in the fracture mode. Hydrogen embrittlement of titanium alloys in the oral cavity sometimes occurs in the presence of fluoride. $^{25-34}$

C) Frictional resistance: It was concluded that the frictional forces of orthodontic brackets and wires are influenced by contact with fluoride-containing solutions. ${ }^{35}$

By reviewing the available literatures, there is little information regarding the effect of topical fluoride treatment on the mechanical properties of different force components of fixed orthodontic appliance. Consequently, the following study was done to evaluate the effect of acidulated and neutral fluoride gels on 1.The loading and unloading mechanical properties of Ni-Ti and SS orthodontic wires. 2. Stress relaxation characteristics of conventional, memory elastomeric chains and Ni-Ti closed coil springs. 
Egyptian

Orthodontic Journal

\section{MATERIAL AND METHODS}

Eighty $0.019 \times 0.025$ inch Ni-Ti and SS orthodontic wires were used. For each wire type, thirty specimens of $25 \mathrm{~mm}$ length were taken as experimental wires and ten specimens were tested in their received condition. Two types of elastomeric chains of clear short modules were used: Conventional and Memory power chain. Thirty specimens were taken from each type of power chain. Thirty Ni-Ti closed coil $200 \mathrm{~g}$ springs of $12 \mathrm{~mm}$ length were used. (American Orthodontics, Cambridge Avenue, Sheboygan, WI, USA).Two topical fluoride gels were used: Acidulated phosphate fluoride gel $(1.23 \%$ acidulated phosphate fluoride [APF], 0.5\% w/v fluoride, $\mathrm{pH}=5.1$; Sultan chemists inc., Englewood NJ. 07631, USA) and Floropal gel $(1.1 \%$ sodium fluoride neutral agent $[\mathrm{NaF}], 0.5 \% \mathrm{w} / \mathrm{v}$ fluoride, $\mathrm{pH}=7$; Ultradent Products, South Jordan, Uttah 84095). Artificial saliva used in this study was Fusayama Meyer artificial saliva. $^{24}$

The wires were cut into length of $25-\mathrm{mm}$ specimens and incubated at $37^{\circ} \mathrm{C}$ in individual $10-\mathrm{ml}$ plastic vials with $2 \mathrm{~mL}$ of one of the fluoride gels or artificial saliva, control, for one hour and half. This exposure time would be equivalent to three months of 1-minute daily topical fluoride treatments. ${ }^{33,34}$

The elastomeric chains were cut into segments of four-linked modules each with a similar unstretched length of $12 \mathrm{~mm}$. Nine jigs consisting of $10 \times 2.5 \times 0.5-\mathrm{cm}$ lengths of stainless steel base were constructed (Fig1). Unlike many previous investigations, the test specimens were held at a constant stretch throughout the test period, including during their transfer to the universal testing machine for force measurement.

The prepared specimens were randomly divided into three equal groups of ten each according to the type of test media. The first is the control group; artificial saliva-immersed group, the second is acidulated phosphate fluoride-immersed group and the third is neutral fluoride - immersed group.

Mechanical testing: All wires were subjected to the three-point bending test on a universal testing machine (model LRX-plus; Lloyd Instruments Ltd., Fareham, UK), at a crosshead speed of $1 \mathrm{~mm} / \mathrm{min}$.Each specimen 
Egyptian

Orthodontic Journal

was loaded to a deflection of $3.1 \mathrm{~mm}$ and then unloaded to zero deflection. The load-deflection curves were recorded and then transferred into stress-strain curves with the computer software (Nexygen-MT; Lloyd Instruments Ltd).

The properties investigated were the loading and unloading flexural Young's modulus, loading and unloading flexural yield strength. The elastomeric chains and NiTi closed coil springs were subjected to stress relaxation test. Force measurement was done at time intervals $0,1,24 \mathrm{hrs}$ and 1, 2, 3 and 4wks (Figure 2).

\section{STATISTICAL ANALYSIS}

Quantitative data were presented as mean and standard deviation values. For parametric data, Student's t-test was used. One way analysis of variance (ANOVA) was used to compare between means of more than two groups. Duncan's and Tukey's tests were used for pair-wise comparison between the means when ANOVA test is significant. For nonparametric data, Mann-Whitney $U$ test and Kruskal-Wallis test were used.

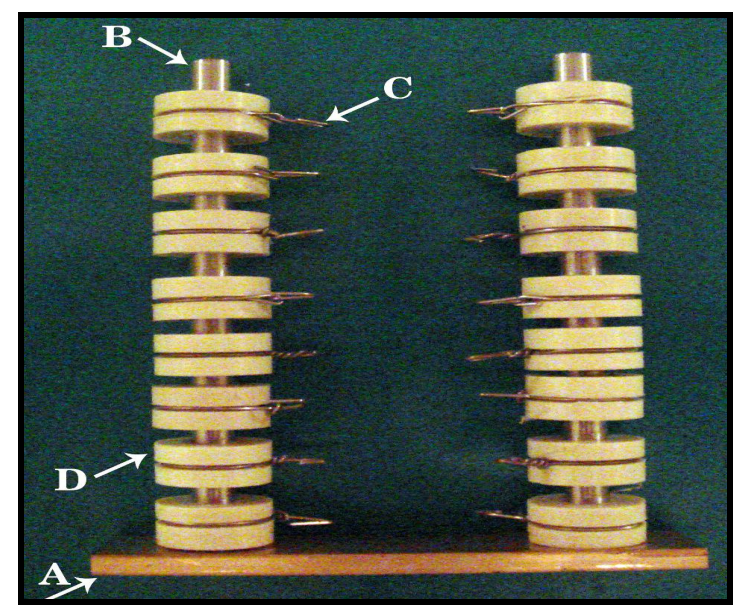

Fig. (1): The customized jig. A- Stainless steel base. B- Stainless steel post, $12 \mathrm{~cm}$ long, set at $60 \mathrm{~mm}$ apart. C- Hook was constructed from $0.9 \mathrm{~mm}$ stainless steel wire to provide an inter hook distance of $24 \mathrm{~mm}$. D- Plastic tubing enabled the hooks to be slid off the jig. 

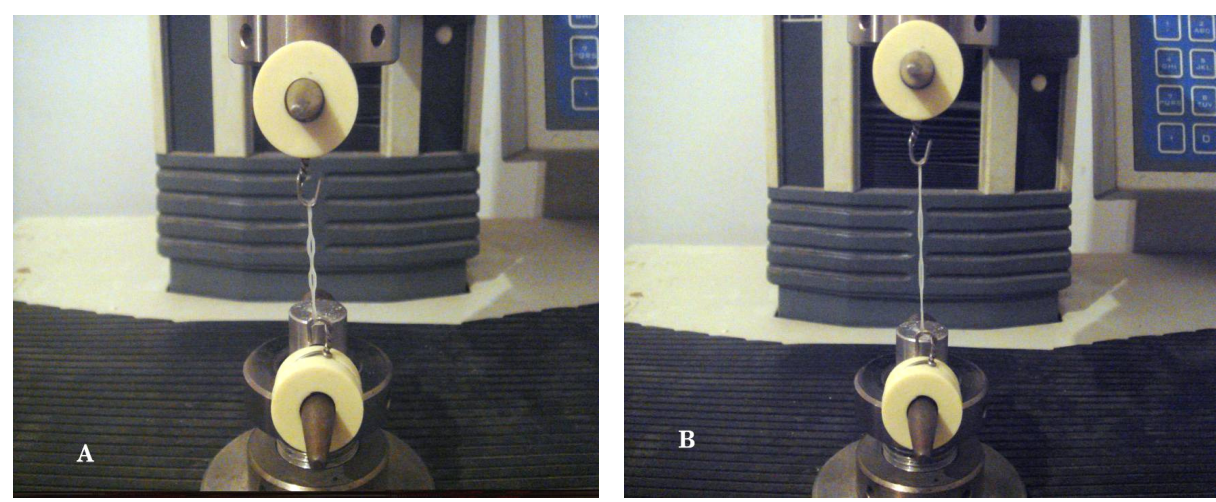

Fig. (2): Power chain specimen of 4-linked modules being tested by universal testing machine.

A- Before activation of the machine. B- After activation.

\section{RESULTS}

The data was collected, tabulated, statistically analyzed and represented in tables (1-3) and figures (3-8).

Table (1): Kruskal-Wallis and Mann-Whitney $U$ test results for comparison of percentage of change in Yield strength and Young's modulus among the three groups within each wire.

\begin{tabular}{|c|c|c|c|c|c|c|c|}
\hline \multirow{2}{*}{$\begin{array}{c}\text { Ortho-dontic } \\
\text { Wire }\end{array}$} & \multirow{2}{*}{\multicolumn{2}{|c|}{$\begin{array}{c}\text { Tested } \\
\text { Mechanical } \\
\text { Properties } \\
\end{array}$}} & \multicolumn{2}{|c|}{$\begin{array}{c}\text { Kruskal-Wallis } \\
\text { Test }\end{array}$} & \multicolumn{3}{|c|}{$\begin{array}{c}\text { Mann-Whitney } \\
\text { U test }\end{array}$} \\
\hline & & & $\mathbf{X}^{2}$ & P-value & I \& II & I \& III & II \& III \\
\hline \multirow{4}{*}{ NiTi } & \multirow{2}{*}{$\begin{array}{c}\text { Yield } \\
\text { strength }\end{array}$} & $\mathbf{L}$ & 2.914 & 0.233 & 0.699 & 0.684 & 0.853 \\
\hline & & Un & 8.217 & $0.016^{* *}$ & $0.034^{*}$ & $0.035^{*}$ & 0.247 \\
\hline & \multirow{2}{*}{$\begin{array}{l}\text { Young's } \\
\text { modulus }\end{array}$} & $\mathbf{L}$ & 0.669 & 0.716 & 0.744 & 0.853 & 0.739 \\
\hline & & Un & 7.910 & $0.019 * *$ & $0.047 *$ & $0.045^{*}$ & 0.353 \\
\hline \multirow{4}{*}{ SS } & \multirow{2}{*}{$\begin{array}{c}\text { Yield } \\
\text { strength }\end{array}$} & $\mathbf{L}$ & 1.146 & 0.564 & 0.423 & 0.393 & 0.579 \\
\hline & & Un & 8.921 & $0.012^{* *}$ & $0.013 * *$ & $0.015^{* *}$ & 0.579 \\
\hline & \multirow{2}{*}{$\begin{array}{l}\text { Young's } \\
\text { modulus }\end{array}$} & $\mathbf{L}$ & 1.350 & 0.509 & 0.587 & 0.353 & 0.353 \\
\hline & & Un & 7.265 & $0.026^{*}$ & $0.006^{* *}$ & $0.007 * *$ & 0.165 \\
\hline
\end{tabular}

*: Significant at $\mathrm{P} \leq 0.05 ; * *$ highly significant at $\mathrm{P} \leq 0.01 ; \mathrm{L}=$ loading; $\mathrm{Un}=$ unloading. 
The effect of both APF (group II) and neutral fluoride agent (group III) was a statistically significant decrease in the unloading Yield strength and Young's modulus of both Ni-Ti and SS wires as compared to their control.

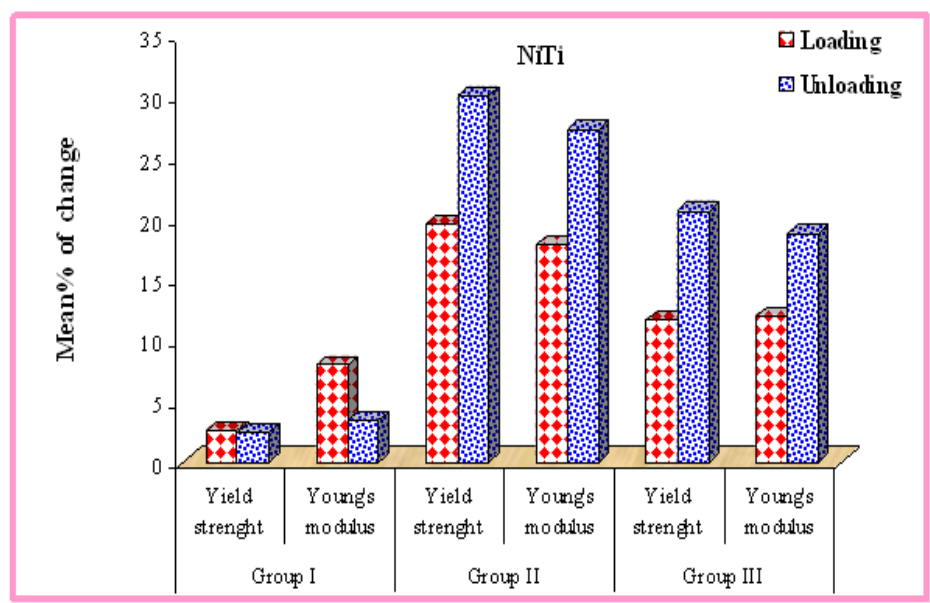

Fig. (3): A bar chart for comparison of the mean percentage of change in the loading and un loading Yield strength and Young's modulus of bending for nickel titanium wires before and after immersion in the different test media.

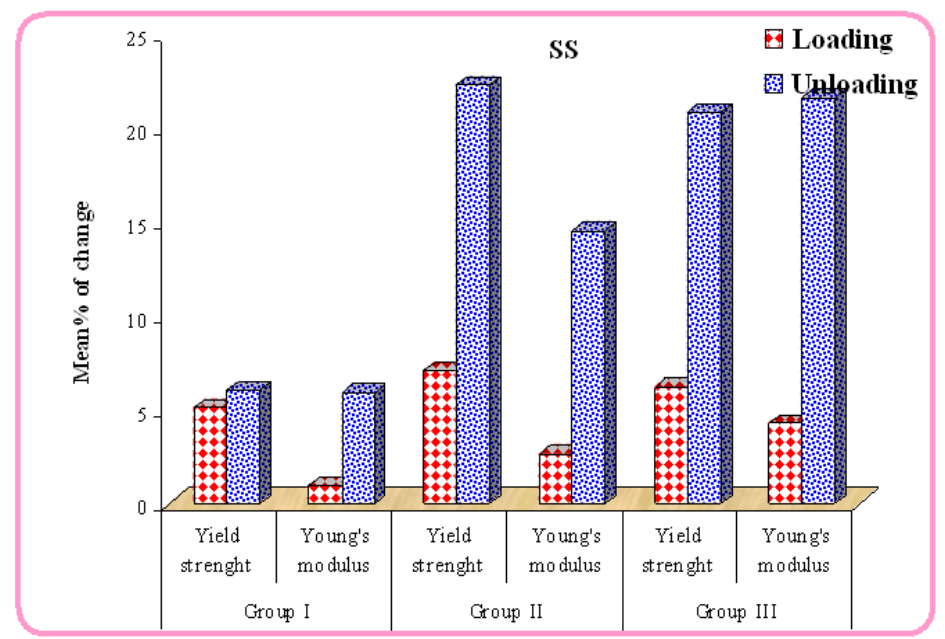

Fig. (4): A bar chart for comparison of the mean percentage of change in the loading and unloading Yield strength and Young's modulus of bending for stainless steel wires before and after immersion in the different test media. 
Egyptian

Orthodontic Journal

Table (2): Mann-Whitney U test for comparison between NiTi and SS orthodontic wires.

\begin{tabular}{|c|c|c|c|c|c|c|c|c|}
\hline & & & \multicolumn{2}{|c|}{ NiTi } & \multicolumn{2}{|c|}{ SS } & \multicolumn{2}{|c|}{$\begin{array}{c}\text { Mann-Whitney } \\
\text { U test }\end{array}$} \\
\hline & & & Mean \% & SD & Mean \% & SD & $\mathbf{Z}$ & P-value \\
\hline \multirow{6}{*}{ 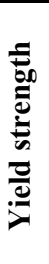 } & \multirow{2}{*}{$\begin{array}{c}\text { Group } \\
\text { I }\end{array}$} & $\mathbf{L}$ & 2.559 & 19.369 & 5.091 & 10.095 & -0.227 & 0.821 \\
\hline & & Un & 2.463 & 29.092 & 6.027 & 16.006 & -0.151 & 0.880 \\
\hline & \multirow{2}{*}{$\begin{array}{l}\text { Group } \\
\text { II }\end{array}$} & $\mathbf{L}$ & 19.534 & 30.881 & 7.085 & 10.270 & -2.495 & $0.013^{* *}$ \\
\hline & & Un & 30.070 & 15.780 & 22.289 & 9.207 & -2.436 & $0.015 * *$ \\
\hline & \multirow{2}{*}{$\begin{array}{c}\text { Group } \\
\text { III }\end{array}$} & $\mathbf{L}$ & 11.646 & 35.538 & 6.182 & 18.005 & -0.302 & 0.762 \\
\hline & & Un & 20.615 & 17.108 & 20.823 & 12.633 & 0.000 & 1.000 \\
\hline \multirow{6}{*}{ 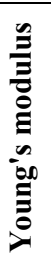 } & \multirow{2}{*}{$\underset{\text { I }}{\text { Group }}$} & $\mathbf{L}$ & 7.931 & 20.810 & 0.912 & 16.053 & -0.907 & 0.364 \\
\hline & & Un & 3.475 & 25.001 & 5.889 & 16.620 & -0.984 & 0.325 \\
\hline & \multirow{2}{*}{$\begin{array}{c}\text { Group } \\
\text { II }\end{array}$} & $\mathbf{L}$ & 17.852 & 22.372 & 2.637 & 16.021 & -2.194 & $0.028^{*}$ \\
\hline & & Un & 27.286 & 27.031 & 14.517 & 8.526 & -2.498 & $0.012 * *$ \\
\hline & \multirow{2}{*}{$\begin{array}{l}\text { Group } \\
\text { III }\end{array}$} & $\mathbf{L}$ & 11.940 & 22.764 & 4.252 & 12.192 & -1.514 & 0.130 \\
\hline & & Un & 18.750 & 21.670 & 21.622 & 9.817 & -0.227 & 0.820 \\
\hline
\end{tabular}

*: Significant at $\mathrm{P} \leq 0.05 ; * *$ : highly significant at $\mathrm{P} \leq 0.01$

In groups I and III: there was no statistically significant difference between mean \% change in Yield strength and Young's modulus of the two orthodontic wires (Loading and Unloading). In group II; the mean \% change in Yield strength and Young's modulus of NiTi wire was statistically significantly higher than SS wire (Loading and Unloading).

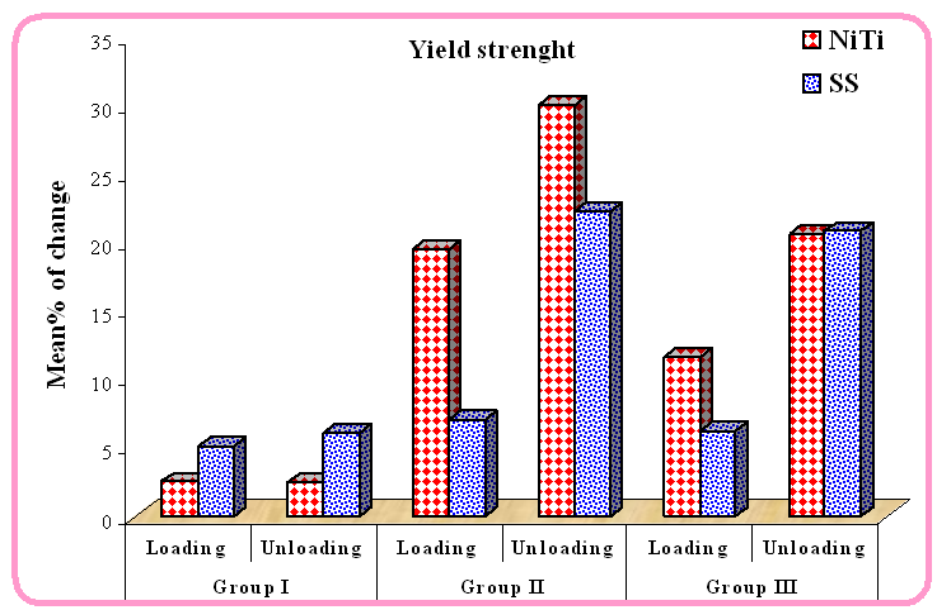

Fig. (5): Bar chart representing comparison between NiTi and SS wires in their mean \% change in loading and unloading Yield strength. 


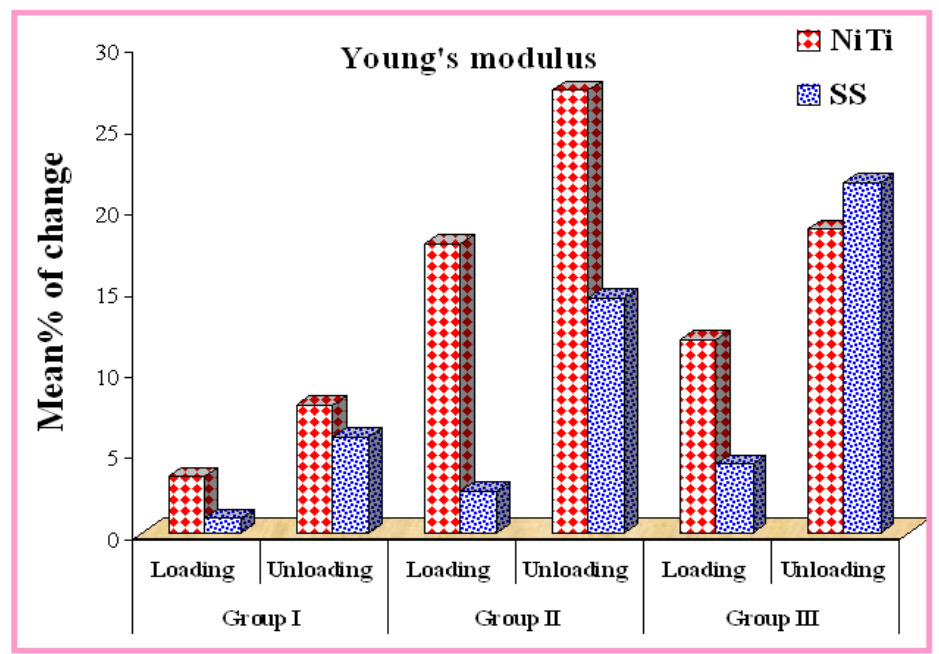

Fig. (6): Bar chart representing comparison between NiTi and SS wires in their mean \% change in loading and unloading Young's modulus.

Table (3): The means, standard deviation values period ( $\mathrm{P}>0.05)$. and results of ANOVA and Duncan's Multiple Range test for comparison among the \% remaining force of the three groups within each orthodontic material over the time intervals.

\begin{tabular}{|c|c|c|c|c|c|c|c|c|}
\hline \multirow{2}{*}{ Time } & \multirow{2}{*}{$\begin{array}{c}\text { Orthodontic } \\
\text { Material }\end{array}$} & \multicolumn{2}{|c|}{ Group I } & \multicolumn{2}{|c|}{ Group II } & \multicolumn{2}{|c|}{ Group III } & \multirow{2}{*}{ P-value } \\
\hline & & Mean \% & SD & Mean \% & SD & Mean \% & SD & \\
\hline \multirow{3}{*}{ 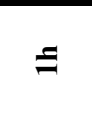 } & CEC & $83.676^{6}$ & 5.847 & $90.007^{\mathrm{a}}$ & 11.610 & $89.439^{a}$ & 19.620 & $0.042 *$ \\
\hline & MEC & 98.011 & 1.633 & 95.251 & 6.971 & 94.80 & 11.394 & 0.177 \\
\hline & $\mathrm{CCS}$ & 99.901 & 0.551 & 99.298 & 1.263 & 99.1 & 3.405 & 0.455 \\
\hline \multirow{3}{*}{ 売 } & $\overline{C E C}$ & $67.668^{b}$ & 3.636 & $83.682^{\mathrm{a}}$ & 12.508 & $74.095^{b}$ & 10.626 & $0.023^{*}$ \\
\hline & MEC & 92.013 & 4.816 & 90.744 & 5.143 & 91.971 & 10.151 & 0.950 \\
\hline & $\mathrm{CCS}$ & 97.387 & 1.789 & 97.588 & 1.523 & 97.987 & 2.108 & 0.870 \\
\hline \multirow{3}{*}{$\Xi$} & $\overline{C E C}$ & $62.947^{b}$ & 5.348 & $78.371^{\mathrm{a}}$ & 11.311 & $67.253^{b}$ & 10.388 & $0.037^{*}$ \\
\hline & MEC & 87.910 & 5.853 & 83.289 & 6.912 & 86.972 & 11.252 & 0.294 \\
\hline & $\mathrm{CCS}$ & 90.347 & 4.507 & 92.760 & 2.594 & 91.744 & 3.328 & 0.576 \\
\hline \multirow{3}{*}{3} & $\overline{C E C}$ & $57.951^{b}$ & 5.284 & $72.345^{\mathrm{a}}$ & 10.880 & $61.678^{b}$ & 11.345 & $0.032 *$ \\
\hline & MEC & 81.040 & 6.175 & 79.636 & 5.268 & 85.672 & 11.491 & 0.491 \\
\hline & $\mathrm{CCS}$ & 84.810 & 0.497 & 85.014 & 4.226 & 87.919 & 4.098 & 0.308 \\
\hline \multirow{3}{*}{ m } & CEC & $54.650^{6}$ & 5.004 & $67.672^{\mathrm{a}}$ & 9.629 & $53.149^{b}$ & 6.295 & $0.002 * *$ \\
\hline & MEC & 76.191 & 6.201 & 75.174 & 8.957 & 76.651 & 8.236 & 0.955 \\
\hline & $\mathrm{CCS}$ & 77.162 & 2.974 & 73.444 & 2.839 & 78.563 & 7.796 & 0.296 \\
\hline \multirow{3}{*}{ 坣 } & $\overline{\mathrm{CEC}}$ & $51.884^{b}$ & 3.237 & $66.418^{\mathrm{a}}$ & 8.891 & $51.759^{b}$ & 7.372 & $0.008^{* *}$ \\
\hline & MEC & 73.060 & 12.330 & 75.926 & 13.600 & 72.472 & 9.537 & 0.888 \\
\hline & $\mathrm{CCS}$ & 79.178 & 2.574 & 71.333 & 5.033 & 76.833 & 13.640 & 0.359 \\
\hline
\end{tabular}

S.D.: Standard Deviation, *: Significant at $P \leq 0.05$, ** highly significant at $P \leq 0.01$; Means with different letters are statistically significantly different according to Duncan's test. 
As regards the conventional elastomeric chains (CEC), groups II and III showed a statistically significant higher mean percentage of remaining force than group I over the first hour. Group II showed the highest mean $\%$ remaining force $(\mathrm{P} \leq 0.05$ at 24-hour, 1 and 2 -week and $\mathrm{P} \leq 0.01$ at 3 and 4 -week test period). While, there was no statistically significant difference between groups I and III which showed the lowest mean \% remaining force.

As regards the memory elastomeric chains (MEC) and Ni-Ti closed coil springs (CCS), there was no statistically significant difference among the three groups throughout the test

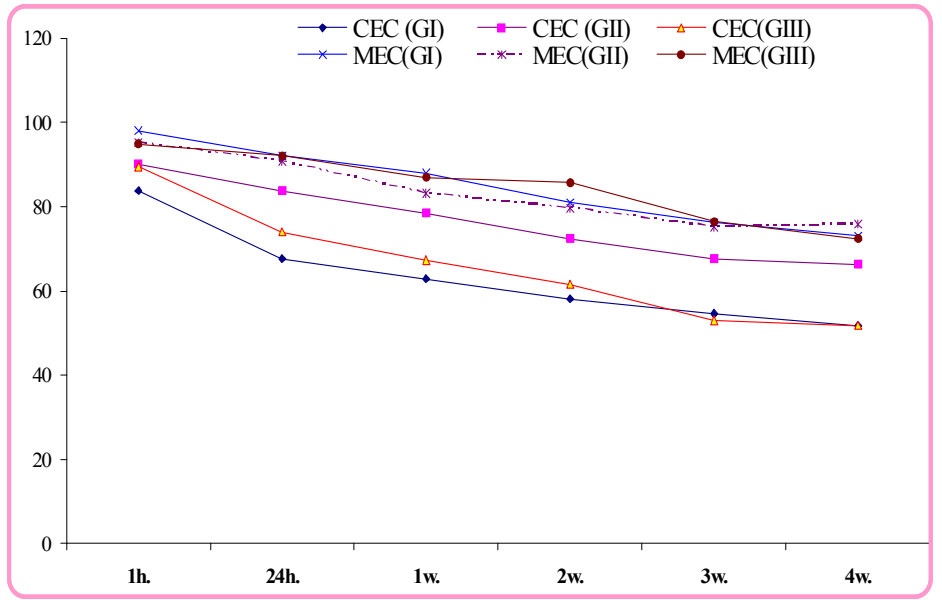

Fig. (7): Line chart representing the changes by time in the percentage of remaining force for the conventional and memory elastomeric chains in the three test media.

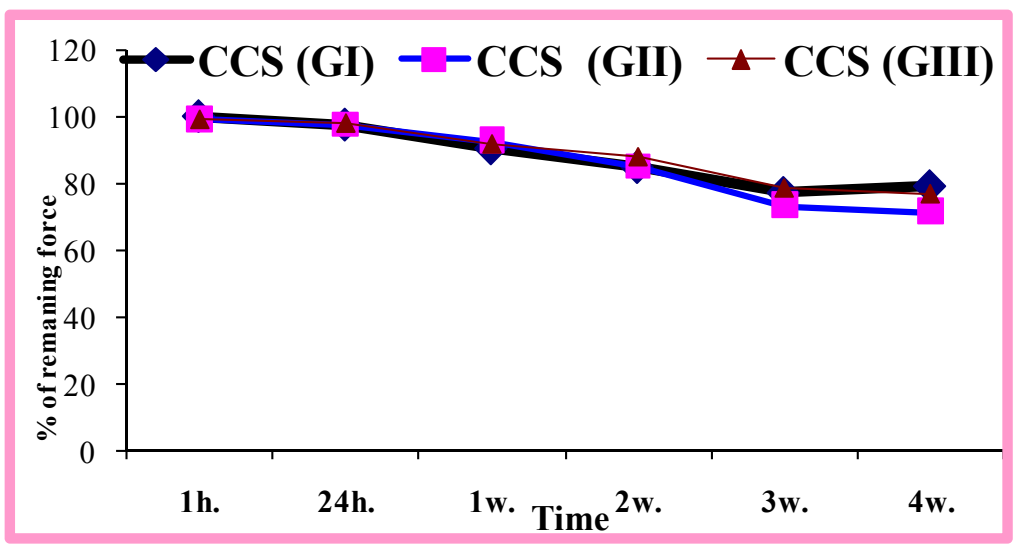

Fig. (8): Line chart representing the changes by time in the percentage of remaining force of the nickel titanium closed coil springs in the three test media. 
Egyptian

Orthodontic Journal

\section{DISCUSSION}

The current study was directed to investigate the effect of fluoride prophylactic agents on the mechanical properties of most force components of fixed orthodontic appliance. Acidulated phosphate fluoride gel and Floropal gel were chosen in this study because of widespread use, identical method of application and fluoride ion concentration, and differences in $\mathrm{pH}$.

I- Bending test: Currently the three-point bending test is preferred as it better simulates clinical inter bracket distances and is more suitable for the very low elastic modulus nickel titanium wire than the previous test. ${ }^{36}$

The most recent specification for orthodontic wires indicates that unloading mechanical testing data shall be reported. ${ }^{37}$ This is because of the fact that unloading properties are responsible for tooth movement. ${ }^{38}$

Young's Modulus is very important clinically as it gives idea about the stiffness or rigidity of the wire within the elastic range. Its value is the slope of the elastic region of the load-deflection curve expressed as the ratio of stress to strain. Yield strength is the stress at which the material begins to function in a plastic manner. At this stress a limited permanent strain usually $0.1 \%$ or $0.2 \%$ of the total permanent strain occurs.

The effect of acidulated and neutral fluoride agent was a statistically significant decrease in the unloading Yield strength and Young's modulus of both Ni-Ti and SS wires as compared to their control. It could be explained by previous reports that hydrofluoric acid (HF), produced according to equation 1, could dissolve the protective oxide layer on the surface of titanium and its alloys $\left(\mathrm{TiO}_{2}\right)$ according to equations 2 and 3. ${ }^{18,26}$

$$
\begin{aligned}
& \mathrm{H}_{3} \mathrm{PO}_{4}+3 \mathrm{NaF} \rightarrow \mathrm{Na}_{3} \mathrm{PO}_{4}+3 \mathrm{HF} \\
& \mathrm{TiO}_{2}+4 \mathrm{HF} \rightarrow \mathrm{TiF}_{4}+2 \mathrm{H}_{2} \mathrm{O} \\
& \mathrm{TiO}_{2}+2 \mathrm{HF} \rightarrow \mathrm{TiOF}_{2}+\mathrm{H}_{2} \mathrm{O}
\end{aligned}
$$

The degradation and the loss of the oxide film expose the underlying alloy, leading to corrosion and the absorption of hydrogen ions from the aqueous-based solution due to the high affinity of titanium with hydrogen resulting in the formation of a brittle titanium hydrides. ${ }^{24}$ Titanium 
hydrides have been reported to form a body-centered tetragonal structure $^{39}$ considered to be the cause of the related degradation of alloy's mechanical properties. ${ }^{40}$

Concerning the SS orthodontic wires; SS passive layer is very complex $^{41}$ and the protective character is due primarily to chromium oxide, $\mathrm{Cr}_{2} \mathrm{O}_{3}{ }^{42}$ Hydrofluoric acid could dissolve this passive layer according to the following equation: $\mathrm{Cr}_{2} \mathrm{O}_{3}+6 \mathrm{HF} \rightarrow 2 \mathrm{CrF}_{3}+3 \mathrm{H}_{2} \mathrm{O}$ Once passive layer degradation occurs; SS has a propensity for hydrogen absorption leading to embrittlement and stress corrosion cracking. ${ }^{29,43}$

On the other hand, the results of exposure to neutral fluoride agent showed a degradation of unloading mechanical property for Ni-Ti and SS wires similar to results of exposure to APF. These findings suggested that fluoride-related alloy effects depend on both $\mathrm{pH}$ and fluoride concentration of the prophylactic agent.

In the current study, the changes were detected only in the unloading properties following fluoride exposure. This might be attributed to the absorbed hydrogen molecules which did not cause any evident effect within the lattice until the wire has been loaded beyond the elastic range, when lattice dislocations and slip occur. Although this has not been studied in orthodontic wires, it has been reported that absorbed hydrogen can be trapped within the SS lattice vacancies, potentially affecting both plastic flow and recovery. ${ }^{43}$ A similar situation might occur with hydrogen absorbed into the $\mathrm{Ni}$-Ti lattice structure. ${ }^{33}$

In vivo, despite fluoride dilution with saliva and the little wire exposure time of only1-minute daily topical fluoride treatment, the actual wire exposure time could be increased because instructions indicate to avoid rinsing for at least 30 minutes after the application and to use the product before bed time. This increased fluoride exposure time could be important as it has been associated with a linear increase in hydrogen absorption and potential alloy mechanical property degradation. ${ }^{24,26}$ 
I. Stress relaxation test: The viscous behavior of the elastic molecules, leads to permanent deformation of the elastics if stretched over an extended period of time. This in addition to the very complex nature of elastics makes it difficult to predict the level of their active force especially under multifactorial medium such as the oral cavity. ${ }^{44}$

\section{Regarding the effect of test media on conventional elastomeric chain:}

In this experiment, the effects of APF on the force decay properties of conventional elastomeric chain were in accordance with other research $^{45}$ in which APF reduced the level of force decay exhibited by elastomers. These results were also in agreement with a previous reported decrease in the force decay rate of the chain elastics in the acidic ( $\mathrm{pH} 4.95)$ solution over four weeks. ${ }^{46}$

This could be related to the $\mathrm{pH}$ of the media. However, it is unlikely to be the complete answer, since it contradicts a previous work ${ }^{47}$ in which the drink Coke ${ }^{\circledR}$ with $\mathrm{pH}$ as low as 2.01 had a greater effect on force loss of elastomeric chain than water alone, suggesting that some factor within the former solution might be modifying the properties. The results also contradict the finding of a previous study ${ }^{48}$ in which, acidity had no significant effect on the mechanical properties of three polyurethane-based orthodontic elastomeric chains.

The difference in our results may be due to presence and nature of fluoride agent since we used high fluoride ion concentration gels. Also, this may be due to the differences in type of the test product and the amount of the extension distance.

On the other hand, in the case of NaF; it is difficult to explain the behavior of the conventional elastomeric chains in the $\mathrm{NaF}$ up to the 1-hour test period. It is possible that the elastomeric chain may absorb the test gels and possibly show some increased stiffness, thereby affecting the measured force. This effect appears to be short lived with the force continuing to fall over the following days.

In the case of artificial saliva, it showed an initial and rapid force loss, but it remained stable over an extended period of time. The effects of 
artificial saliva on the pattern of force decay of conventional elastomeric chain in this experiment were more or less in accordance with the results of the previous researches. 9,44

\section{Regarding the effect of test media on memory elastomeric chain:}

There was no statistically significant difference in the force levels over the examination period among those specimens stored in artificial saliva, APF or NaF gel $(\mathrm{P}>0.05)$. In the all test media, MEC showed a relatively stable force over an extended period of time of about one week, and began to decay from the second to the fourth week by about 20 to $25 \%$ of its original force. These findings were more or less in accordance with the results of a previous study in which the force decay of fluoride release, memory and conventional elastic power chains were studied under dry and wet conditions. ${ }^{44}$

Regarding the effect of test media on nickel titanium closed coil springs: The results when considered over the whole test period showed that there was no statistically significant difference among the three test media in the mean percentage of remaining force $(\mathrm{P}>0.05)$. The rate of force loss was almost identical for each of the three test media throughout the test period. These findings were in accordance with previous studies. $9,48,49$ The produced constant force is due to superelasticity of the NiTi closed coil springs. ${ }^{50}$

\section{CONCLUSIONS}

1- Both $\mathrm{pH}$ and fluoride concentration are important factors in the breakdown of the protective oxide layer of nickel-titanium and stainless steel, leading to potential hydrogen absorption and associated mechanical property degradation.

2- Using topical gels with high concentrations of fluoride in association with stainless steel or nickel-titanium orthodontic wires is considered a factor in prolongation of orthodontic treatment time.

3- Nickel-titanium coil springs and memory elastomeric chains were not significantly affected by the test media. 
Egyptian

Orthodontic Journal

\section{RECOMMENDATION}

1. During the long-period orthodontic treatment, the fluoride-containing products should be carefully used and prescribed according to the treatment phase and the alloy used to minimize unexpected damage on orthodontic wires.

2. Nickel-titanium coil springs and memory power chains are recommended for delivering steady-continuous force for a period up to four weeks.

\section{REFERENCES}

1. Samuels RHA, Rudge SJ and Mair LH: A comparison of the rate of space closure using a nickel-titanium spring and an elastic module: a clinical study. Am J Orthod Dentofac Orthop. 1993; 103(5):464-7.

2. Sonis AL: Comparison of NiTi coil springs vs. elastics in canine retraction. J Clin Orthod. 1994; 28:293-5.

3. Samuels RHA, Rudge SJ and Mair LH: A clinical study of space closure with nickel-titanium closed coil springs and an elastic module. Am J Orthod Dentofac Orthop. 1998; 114(1):73-9.

4. Von Fraunhofer JA, Bonds PW and Johnson BE: Force generation by orthodontic coil springs. Angle Orthod. 2002; 63(2):145-8.

5. Dixon V, Read MJF, O'Brien KD, Worthington HV and Mandall NA: A randomized clinical trial to compare three methods of orthodontic space closure. Am J Orthod Dentofac Orthop. 2002; 29(1):31-6.

6. Nightingale $\mathrm{C}$ and Jones SP: A clinical investigation of force delivery systems for orthodontic space closure. J Orthod. 2003; 30(3):229-36.

7. Bokas $\mathrm{J}$ and Woods $\mathrm{M}$ : A clinical comparison between nickel titanium springs and elastomeric chains. Aust Orthod J. 2006; 22(1):39-46.

8. Santos ACS, Tortamano A, Naccarato SRF, Rodriguez GCD and Vigorito JW: An in vitro comparison of the force decay generated by different commercially available elastomeric chains and NiTi closed coil springs. Braz Oral Res. 2007; 21(1):51-7. 
9. Cacciafesta V, Sfondrini MF, Calvi D, Scribante A: Effect of fluoride application on shear bond strength of brackets bonded with a resin -modified glass- ionomer. Am J Orthod Dentofac Orthop. 2005; 127(5):580-3.

10. Siirilä HS and Könönen M: The effect of oral topical fluorides on the surface of commercially pure titanium. Int $\mathrm{J}$ Oral Maxillofac Implants. 1991; 6:50-4.

11. Pröbster L and Lin W: Hüttemann H. Effect of fluoride prophylactic agents on titanium surfaces. Int J Oral Maxillofac Implants. 1992; 7:390-4.

12. Könönen MHO, Lavonius ET and Kivilahti JK: SEM observations on stress corrosion cracking of commercially pure titanium in a topical fluoride solution. Dent Mater. 1995; 11:269-72.

13. Boere G: Influence of fluoride on titanium in an acidic environment measured by polarization resistance technique. J Appl Biomater. 1995; 6:283-8.

14. Toumelin-Chemla F, Rouelle F and Burdairon G: Corrosive properties of fluoride-containing odontologic gels against titanium. J Dent. 1996; 24:109-15.

15. Mimura $\mathrm{H}$ and Miyagawa $\mathrm{Y}$ : Electrochemical corrosion behavior of titanium castings: Part 1 . Effects of degree of surface polishing and kind of solution. Jpn J Dent Mater Dev. 1996; 15:283-95.

16. Oda Y, Kawada E, Yoshinari M, Hasegawa $\mathrm{K}$ and Okabe T: The influence of fluoride concentration on the corrosion of titanium and titanium alloys. Jpn J Dent Mater Dev. 1996; 15:317-22.

17. Reclaru L and Meyer JM: Effects of fluorides on titanium and other dental alloys in dentistry. Biomaterials. 1998; 19:85-92.

18. Nakagawa M, Matsuya S, Shiraishi T and Ohta M: Effect of fluoride concentration and $\mathrm{pH}$ on corrosion behavior of titanium for dental use. J Dent Res. 1999; 78:1568-72.

19. Nakagawa M, Matsuya S and Udoh K: Corrosion behavior of pure titanium and titanium alloys in fluoride-containing solutions. Dent Mater J. 2001; 20:305-14. 
20. Nakagawa $M$, Matsuya $S$ and Udoh $K$ : Effects of fluoride and dissolved oxygen concentrations on the corrosion behavior of pure titanium and titanium alloys. Dent Mater J. 2002; 21:83-92.

21. Huang $\mathrm{HH}$ : Effects of fluoride concentration and elastic tensile strain on the corrosion resistance of commercially pure titanium. Biomaterials. 2002; 23: 59-63.

22. Schiff N, Grosgogeat B, Lissac M and Dalard F: Influence of fluoride content and $\mathrm{pH}$ on the corrosion resistance of titanium and its alloys. Biomaterials. 2002; 23: 1995-2002.

23.Al-Mayouf, Al-Swayih AA, Al-Mobarak NA and Al-Jabab AS: The effect of fluoride on the electrochemical behavior of Ti and some of its alloys for dental applications. Mater Corrosion. 2004; 55:524-30.

24. Mabilleau G, Bourdon S, Joly-Guillou ML, Filmon R, Baslé MF and Chappard D: Influence of fluoride, hydrogen peroxide and lactic acid on the corrosion resistance of commercially pure titanium. Acta Biomaterialia. $2006 ; 2: 121-9$.

25. Yokoyama K, Kaneko K, Moriyama K, Asaoka K, Sakai J and Nagumo M: Hydrogen embrittlement of $\mathrm{Ni}$-Ti superelastic alloy in fluoride solution. J Biomed Mater Res. 2003; 65A:182-7.

26. Kaneko K, Yokoyama K, Moriyama K, Asaoka K, Sakai J and Nagumo M: Delayed fracture of beta titanium orthodontic wire in fluoride aqueous solutions. Biomater. 2003; 24:2113-20.

27. Ogawa T, Yokoyama K, Asaoka K and Sakai J: Hydrogen absorption behavior of beta titanium alloy in acid fluoride solutions. Biomater. 2004; 25: 2419-25.

28. Kwon YH, Cheon YD, Seol HJ, Lee JH and Kim HI: Changes on NiTi orthodontic wires due to acidic fluoride solution. Dent Mater J. 2004; 23:557-65.

29. Prymak O, Klocke A, Kahl-Nieke B and Epple M: Fatigue of orthodontic nickel-titanium (NiTi) wires in different fluids under constant mechanical stress. Mater Scien Eng. 2004; 378:110-4. 
30. Kaneko K, Yokoyama K, Moriyama K, Asaoka K and Sakai J: Degradation in performance of orthodontic wires caused by hydrogen absorption during short-term immersion in $2.0 \%$ acidulated phosphate fluoride solution. Angle Orthod. 2004; 74:487-95.

31. Yokoyama K, Kaneko K, Ogawa T, Moriyama K, Asaoka K and Sakai J: Hydrogen embrittlement of work- hardened Ni-Ti alloy in fluoride solutions. Biomater. 2005; 26:101-8.

32. Kwon YH, Seol HJ, Kim HI, Hwang KJ, Lee SG and Kim KH: Effect of acidic fluoride solution on beta titanium alloy wire. J Biomed Mater Res B Appl Biomater. 2005; 73:285-90.

33. Walker MP, White RJ and Kula KS: Effect of fluoride prophylactic agents on the mechanical properties of nickel-titanium-based orthodontic wires. Am J Orthod Dentofac Orthop. 2005; 127:662-9.

34. Walker MP, Ries D, Kula K, Ellis M and Fricke B: Mechanical Properties and Surface Characterization of Beta Titanium and Stainless Steel Orthodontic Wire Following Topical Fluoride Treatment. Angle Orthod. 2007; 2:342-8.

35. Kao CT, Ding SJ, Wang CK, He H, Chou MY and Huang TH: Comparison of frictional resistance after immersion of metal brackets and orthodontic wires in a fluoride-containing prophylactic agent. Am J Orthod Dentofac Orthop. 2006; 130:568.e1-9.

36. O'Brien WJ. Dental Materials and Their Selection. $4^{\text {th }}$ ed. Chicago, Ill: Quintessence Publishing Co; 2008.

37. American National Standard/American Dental Association Specification No. 32: Orthodontic Wires. Chicago, Ill: American Dental Association; 2000.

38. Rucker BK, Kusy RP. Elastic flexural properties of multistranded stainless steel versus conventional nickel titanium archwires. Angle Orthod. 2002; 72:302-9.

39. Nam TH, Shimizu K, Saburi T, Nenno S. Crystal structure of a hydride formed by electrochemical hydrogenation in a Ti-Ni-Al alloy. Mater Trans JIM 1989; 30:539-48. 
40. Yokoyama K, Hamada K, Asaoka K. Fracture analysis of hydrogencharged nickel-titanium superelastic alloy. Mater Transa 2001; 42:141-4.

41. Oh KT, Kim YS, Park YS, Kim KN. Properties of super stainless steels for orthodontic applications. J Biomed Mater Res B Appl Biomater. 2004; 69 :183-94.

42. Huang HH. Corrosion resistance of stressed NiTi and stainless steel orthodontic wires in acid artificial saliva. J Biomed Mater Res A. 2003; 66:829-39.

43. Hirth JP. Effects of hydrogen on the properties of iron and steel. Metallurg Trans 1980; 11A:861-90. Ferriter J, Meyers C and Lorton L: The effect of hydrogen ion concentration on the force degradation rate of orthodontic polyurethane chain elastics. Am J Orthod Dentofac Orthop. 1990; 98:404-10.

44. Abdel-Kader HM and Ibrahim SA: Force decay of fluoride release, memory and conventional elastic power chains studied under dry and wet conditions. Al-Azh J Dent Scien. 2000; 3:117-23.

45. Von Fraunhofer JA, Coffelt M-TP and Orbell GM: The effects of artificial saliva and topical fluoride treatments on the degradation of the elastic properties of orthodontic chains. Angle Orthod. 1992; 4:265-74.

46. Ferriter J, Meyers C and Lorton L: The effect of hydrogen ion concentration on the force degradation rate of orthodontic polyurethane chain elastics. Am J Orthod Dentofac Orthop. 1990; 98:404-10.

47. Nattrass C, Ireland AJ and Sherriff M: The effect of environmental factors on elastomeric chain and nickel titanium coil springs. Eur $\mathrm{J}$ Orthod. 1998; 20:169-76.

48. Stevenson JS and Kusy RP: Force application and decay characteristics of untreated and treated polyurethane elastomeric chains. Angle Orthod. 1994; 6:455-67.

49. Han S and Quick DC: Nickel-titanium spring properties in a simulated oral environment. Angle Orthod. 1993; 63(1):67-72.

50. Manhertsberger $\mathrm{C}$ and Seidenbusch W: Force delivery of Ni-Ti coil springs. Am J Orthod Dentofac Orthop 1996; 109:8-21. 